\title{
$\$$ Research Square

\section{Objective Understanding of Front of Pack Warning Labels Among Mexican Children of Public Elementary Schools. A Randomized Experiment}

\section{Alejandra Contreras-Manzano}

National Institute of Public Health: Instituto Nacional de Salud Publica

Alejandra Jauregui ( $\square$ alejandra.jauregui@insp.mx )

Instituto Nacional de Salud Publica https://orcid.org/0000-0001-9158-2007

\section{Jorge Vargas}

National Institute of Public Health: Instituto Nacional de Salud Publica

\section{Claudia Nieto}

National Institute of Public Health: Instituto Nacional de Salud Publica

\section{Adriana Granich}

National Institute of Public Health: Instituto Nacional de Salud Publica

María de Lourdes Alemán Escobar

National Institute of Public Health: Instituto Nacional de Salud Publica

\section{Armando Olvera}

National Institute of Public Health: Instituto Nacional de Salud Publica

\section{Carlos Cruz-Casarrubias}

National Institute of Public Health: Instituto Nacional de Salud Publica

\section{Ana Munguía-Serrano}

National Institute of Public Health: Instituto Nacional de Salud Publica

\section{Barquera Simón}

National Institute of Public Health: Instituto Nacional de Salud Publica

\section{Research}

Keywords: Front-of the-pack labeling, warning labels, children, marketing, cartoon characters, objective understanding, ultra-processed foods and beverages.

Posted Date: July 12th, 2021

DOI: https://doi.org/10.21203/rs.3.rs-691027/v1

License: (c) (1) This work is licensed under a Creative Commons Attribution 4.0 International License. Read Full License 


\section{Abstract}

Background. Warning Labels (WL) are a new approach which highlight excessive amounts of critical nutrients in processed foods or beverages in order to discourage consumption of unhealthful products. This study aimed to evaluate among Mexican school children, the objective understanding of traditional and numeric WL considered by the Mexican regulation. To identify the impact of cartoon characters in the objective understanding of the WL and, to test some communication strategies to facilitate the correct use of the WL.

Methods. We carried out a randomized experiment in July of 2019 in public elementary schools Morelos, Mexico. Participants were randomly assigned to one of four groups: 1) Nutrient Facts Panel (NF), 2) Nutrient Facts Panel with cartoon characters (NF+C), 3) Warning Labels (WL), and 4) Warning Labels with cartoon characters $(\mathrm{WL}+\mathrm{C})$. After allocation, children assigned to both $W L$ groups ( $W L$ or $W L+C)$, were randomly required to watch simultaneously two posters or a video explaining how to correctly interpret WLs. Logistic regression models adjusted by sex, age and cluster (school) were fitted.

Results. The proportion of children correctly choosing the healthiest or the least healthy option was higher for WL groups (56.8\%, 95\% Cl; 40.8-72.8) compared to all NF groups $(24.3 \%, 95 \% \mathrm{Cl} ; 20.4-28.3, \mathrm{p}<0.05)$. The objective understanding of traditional WL was higher (28.7\%, 95\% Cl: 22.8-35.4) than the numeric WL (19\%, 95\%Cl: 14.2-25.0, $\mathrm{p}<0.05)$. For choosing the unhealthiest products, WL group responded correctly in a higher proportion when using traditional WL $(58.7 \%, 95 \% \mathrm{Cl}: 36.4-81.1)$ in comparison to $\mathrm{WL}+\mathrm{C}$ group $(48.8 \%, 95 \% \mathrm{Cl}$ : 25.4-64.2, $\mathrm{p}<0.05)$. By tool of communication, the video was 2.23 times more helpful than the posters to the correct interpretation of the WL $(p<0.05)$, being 2.41 times more helpful for choosing the healthiest item $(p<0.05)$ and 1.57 for choosing the unhealthiest choice $(p<0.05)$.

Conclusions. In scholar Mexican children, WL were useful to identify easily and quickly healthier and unhealthier packaged products in comparison to NF. Importantly, numeric WL seemed to be as effective as WL to help children identify healthy and unhealthy products. Cartoons displayed on the packages reduced the objective understanding of the WL, especially for breakfast cereals and milks for which cartoons where perceived as the unhealthiest ones.

\section{Introduction}

Mexico is one of the leading countries worldwide in the obesity epidemic and has the highest increase rates in childhood obesity. [1-3] In total, 35.6\% and 38.4\% of Mexican children and adolescents, respectively, live with obesity in 2018-19 [4]. Ultra-processed products, with high quantities of saturated fat and/or added sugar, have contributed to the development of this public health problem [5-7]. Among Mexican school-aged children and adolescents, ultra-processed products represent $25 \%$ of the total calories consumed [8].

Warning Labels (WL) are a new labelling approach, highlighting excessive amounts of added sugar, sodium or saturated fats in processed foods or beverages in order to discourage the consumption of unhealthful products [9]. WL have been implemented in Chile (2016) [10], Peru (2018) [11] and Mexico [12], were approved for their implementation in Uruguay (2021) [13], and are being considered as the mandatory front of package labelling in Brazil [14]. After one year of implementation in Chile (2017), purchases of "high-in" beverages decreased 22.8 $\mathrm{mL} /$ capita/day, whereas purchases of products without labels increased [15]. Some of these regulations also considered restrictions for marketing strategies and advertising to children for products with one or more WL [12, 16]. 
However, one of the limitations of the WL regulations implemented in Chile and Peru is that small products $\left(<50 \mathrm{~cm}^{2}\right.$ in Peru and $<30 \mathrm{~cm}^{2}$ in Chile) are not labelled because the size of the WL does not fit these packages. Taking advantage of this exception, manufacturers in Peru reduced the size of some of their products to avoid WL $[17,18]$. Therefore, many small products high in sugar, fat and/or calories (e.g., candies, chocolates and cookies), are not labelled with WL and, thus, may use cartoon characters or other marketing strategies directed to children, making this population more vulnerable to make unhealthy food choices [19]. Studies suggest that marketing strategies targeting children and youth may change perceptions of product taste, attract more attention [20], increase product's appeal [21] and influence children's food preferences, consumption patterns, and purchase requests. Further, cartoon characters help children recognize the brand [22,23], and aim to create a positive attitude and loyalty towards the product [24]. In addition, food and beverages mostly frequently promoted to children are high in saturated fat, sugar or sodium [23].

WL are one of the most understood front of the package labelling by adults across countries [25]. Evidence also indicates that WL are well understood among adolescents [26]. However, few studies have explored the understanding of WL among school-aged children. In Uruguay, school-aged children were abler to correctly identify a product with high content of a critical nutrient when using WL compared to GDA or Multiple Traffic Light (MTL) [27]. In Brazilian children the perceived healthfulness of an unhealthy product (i.e. chocolate flavoured milk and yogurt) decreased when using WL compared to the GDA system [28]. Additionally, scarce evidence exists regarding the influence of marketing strategies to children, such as cartoon characters, on WL understanding [27].

Based on previous experiences and to prevent small products waving WL, the WL regulation in Mexico considers the implementation of traditional WL ('Excess in...' labels or labels in captions) for regular size pre-packaged products with excessive contents of added sugar, sodium or fat, as well as numeric WL for small $\left(<40 \mathrm{~cm}^{2}\right)$ or products in returnable packaging [12]. Numeric WL indicate the total number of WL a small product has with a single label (Fig. 1). However, to date no study has explored the understanding of numeric WL among consumers.

Communication strategies aiming to improve the use and understanding of front-of-pack nutritional labels are key aspects to be considered during the implementation of new regulations [29]. For example, in Chile a communication campaign was launched along with the implementation of WL. Studies indicate that over $90 \%$ of consumers understood WL at 6 and 18 months after their implementation [30] A randomized experiment in Peruvian children explored the use of an emoji to rate the emotions associated with a product, finding that WL had a greater effect than MTL in associating negative emoji for unhealthy products. [31] In Mexico, no studies have been developed to investigate the effectiveness of food labelling communication strategies among children.

We carried out a randomized experiment to investigate the objective understanding of traditional WL and numeric WL among Mexican school children, and whether cartoon characters influenced the understanding. We also tested some communication strategies to facilitate the correct use of the WL.

\section{Material And Methods}

Design: We carried out a split-plot design with four factors unblinded randomized experiment in July 2019. The Ethics, Research and Biosafety committees of the Mexican National Institute of Public Health evaluated and approved this study (approval number: 7-68S4-P62-19).

Recruitment The study was conducted in public elementary schools selected by convenience in the state of Morelos, Mexico. School principals from four selected elementary schools were invited to participate in the study. After 
explaining study objectives, activities, benefits and potential risks for the children, three of them agreed to participate in the study. Children from 7 to 12 years old from all grades (i.e., from first to sixth grade in the Mexican school system) were invited to participate in the study. Written consent forms were sent home with children and only those with consent to participate by their parents or guardians were included. Before starting study procedures, children were asked to assent to participate in the study.

Participant's allocation. Participants were randomly assigned to one of four groups: 1) Nutrient Facts Panel (NF), 2) Nutrient Facts Panel with cartoon characters (NF + C), 3) Warning Labels (WL), and 4) Warning Labels with cartoon characters $(W L+C)$. Randomization was done with raffle tickets indicating children's allocation (i.e., children randomly chose a ticket from a basket). Blinding of participants or researchers was not possible given the nature of the intervention.

Experiment. After allocation, children assigned to both $\mathrm{WL}$ groups (WL or $\mathrm{WL}+\mathrm{C}$ ) were randomly required to watch two posters, both displayed together on a desk, (Image 2A) or a video (Image 2B) explaining how to correctly interpret WLs. Children were not given any other explanation on how to interpret WL. Children allocated to other study groups (NF and NF + C) were not provided with any interpreting aids.

The video (Supplementary Video 1) showed examples of products with and without WL (Image 1), visually displaying approval (i.e., a tick) or disapproval (i.e., a cross), respectively, and suggested choosing the healthiest food product (i.e., the one with no WL, with the fewest labels or the smaller number). It also mentioned that minimally processed foods were the healthiest [32]. On the other hand, the posters (50x60 cm)(Image 2) displayed products along with smiling emoji if the product had no WL or dislike emoji if the product had two or more WL, based on previous emoji association with perceptions of healthiness with front of package labelling in children [31]. The key messages of both interpreting aids (i.e., video and posters) were piloted and tested in school-age children to "choose the healthiest" and "it is better if it does not have a warning label", based on the Chilean government WL campaign $[11,29]$.

A set of fictitious products were used per study group. Each set contained a total of 42 food products from 6 food groups, with different packaging sizes: 3 regular size groups (beverages in disposable packaging, breakfast cereals, and dairy beverages), and 3 small size products or products with returnable packaging groups (i.e., candies, cookies and beverages in returnable packaging) (Image 4 and 5).

All packaging looked the same across study groups, except for the WL and/or the cartoon characters displayed. Products showed no brands, no other labels, claims or advertising. In order to include a range of products with varying nutritional quality, the nutritional information and ingredients list of similar real products was used. This information was used to evaluate the nutritional quality of food products, according to the Mexican Nutrient Profile (Supplementary Table 1). Additionally, the following variations were considered in the set of products used in each study group:

1) Warning labels: Products used in the NF group only displayed the Nutrient Facts Panel, while for WL groups (WL and $\mathrm{WL}+\mathrm{C}$ ) the products displayed the Nutrient Facts Panel and the corresponding $\mathrm{WL}$, going from zero warnings (the healthiest product) to six warnings (the unhealthiest product). Traditional WL (Image 4) were displayed in regular size food products, whereas numeric WL (Image 5) were displayed in small size products or products with returnable packaging. For regular size food products $\left(>10 \mathrm{~cm}^{2}\right)$ the Nutrient Facts Table in the back of the package was displayed (Image 4). 
2) Cartoon characters: Products used in cartoon characters' groups $(\mathrm{NF}+\mathrm{C}$ and $\mathrm{WL}+\mathrm{C})$ included one product with a cartoon character. This product displayed $4 \mathrm{WL}$ in the $\mathrm{WL}+\mathrm{C}$ group or the equivalent product in the $\mathrm{NF}+\mathrm{C}$. For candies group, non-nutrition facts table, neither cartoon character was displayed in the product package.

Children were asked to sit in front of a table. Initially, children were shown a set of seven products corresponding to the first food group (e.g., breakfast cereals). For this purpose, children were required to close their eyes while products were set on the table to avoid them from looking at the products before the experiment started. Then they were allowed to open their eyes and were asked: Which food product is the healthiest? Children chose one food product among the seven options. Then, children were asked: Which food product is the least healthy? Again, children chose one food product among the six remaining options. In both occasions, the time required to make a decision (i.e., time in seconds, starting when the child opened his/her eyes, up to when a decision was made) as well as the product chosen by the child were registered. This process was repeated for each of the remaining five food groups.

The order in which food groups were presented was randomly assigned using a total of six possible combinations for the three regular size groups and for the three small size groups. Additionally, the way in which the set of seven products was displayed on the table varied in order to avoid a sequence or order bias. Once their participation was concluded, children were rewarded with stickers and the fruit of their choice (e.g., a banana, apple or an orange). Additionally, the school received one soccer or volleyball ball per classroom for participating in the research project.

\section{Outcomes.}

The proportion of children correctly identifying the healthiest product (i.e., product with no WL), the least healthy product (i.e., product with six WL) and both products (i.e., healthiest and least healthy product) was considered as the primary outcome. The time required to make a decision among study groups was considered as the secondary outcome.

Covariates. Before allocation, children answered a brief questionnaire that collected socio-demographic characteristics like sex, age, literacy, and habitual food shopping location.

\section{Analysis.}

Based on previous studies among Mexican consumers [25, 26, 33], and considering an alpha of 0.05 a power of $80 \%$ assuming a usual correlation between them of 0.1 (Cohen, 1992) [34], we estimated that a total of 70 children were required per study group to detect a difference of proportions of 10 percentage points between the WL (i.e. traditional and numeric) and comparison groups. Considering the four study groups we estimated that a sample size of 280 school children was required. Differences in the characteristics of the four groups of study were explored by using chi-square test.

Comparisons between $\mathrm{WL}(\mathrm{WL}$ and $\mathrm{WL}+\mathrm{C})$ and $\mathrm{NF}(\mathrm{NF}$ and $\mathrm{NF}+\mathrm{C})$ were used to explore the overall objective understanding of $\mathrm{WL}$ and the time required to make a decision. To examine the objective understanding of $\mathrm{WL}$, logistic regression models were fitted to estimate the adjusted proportion (by sex, age and school cluster) of children correctly identifying the healthiest option, the least healthy option and both, across these groups. To examine differences in the time required to make a decision, quantile regression models were fitted to estimate the adjusted median time (by sex, age and school cluster) across NF or WL groups. 
Differences in the objective understanding of traditional and numeric WL, as well as in the effectiveness of communication strategies to explain the correct use of WL, were explored among children assigned to WL groups $(\mathrm{WL}$ and $\mathrm{WL}+\mathrm{C}$ ) only. To explore differences in the objective understanding between traditional and numeric $\mathrm{WL}$, Logistic regression models were fitted to estimate the adjusted proportion (by sex, age and school cluster) of children correctly identifying the healthiest option, the least healthy option and both, across products labeled with traditional and numeric WL. Differences in the time required to make a decision were also explored among these groups using a similar approach as the one described above.

To compare the effectiveness of communication strategies to explain the correct use of WL, the adjusted proportion of children correctly identifying the healthiest product, the least healthy product or both across communication strategies (video or poster) was estimated through logistic regression models. Generalized linear regression models adjusted by sex, age and cluster (school) were used to estimate the difference of median of seconds among communication strategies.

To estimate the impact of cartoon characters in the ability of children to choose correctly, a logistic regression model was fitted to estimate the adjusted proportion (by sex, age and school cluster) of children correctly identifying the healthiest product, the unhealthiest product and both, across cartoon character groups. Stratified proportions for NF and $\mathrm{WL}$ groups were displayed.

Stata v14 software was used to develop the statistical analysis.

\section{Results}

A total of 410 elementary school children (NF:120 (29.3\%), NF + C: 83 (20\%), WL: 109 (26.6\%), WL + C: 96 (23.4\%)) were included in this study (Table 1). Half were males, $58.3 \%$ were aged between 6 and 9 years old, and $41.7 \%$ between 9 and 13 years old. Most (58.5\%) were from School \#2, 24.4\% from School \#1 and 17.1\% from School \#3. In total, $8.3 \%$ reported not been able to read. No differences were observed across study groups.

Supplementary Table 2 shows the objective understanding of WL across study groups, type of warning label (traditional or numeric) and food group. 
Table 1

Socio-demographic characteristics of children

\begin{tabular}{|c|c|c|c|c|c|c|}
\hline \multirow[t]{3}{*}{ n (\%) } & Total & NF & $\mathrm{NF}+\mathrm{C}$ & WL & $W L+C$ & \multirow[t]{3}{*}{$p$ value } \\
\hline & $410(100)$ & $120(29.3)$ & $83(20.0)$ & $109(26.6)$ & 96 (23.4) & \\
\hline & $\mathrm{n}(\%)$ & n (\%) & n (\%) & n (\%) & n (\%) & \\
\hline \multicolumn{7}{|l|}{ Sex } \\
\hline Male & $205(50)$ & $63(62.5)$ & $45(52.9)$ & $54(49.5)$ & $43(44.8)$ & \multirow[t]{2}{*}{.649} \\
\hline Female & $205(50)$ & $57(47.5)$ & $40(47.1)$ & $55(40.5)$ & 53 (55.3) & \\
\hline \multicolumn{7}{|l|}{ Age } \\
\hline $6-9$ y old & 239 (58.3) & $67(55.8)$ & $52(61.2)$ & $61(56.0)$ & $59(61.5)$ & \multirow[t]{2}{*}{.746} \\
\hline $9-13$ y old & $171(41.7)$ & $53(44.2)$ & 33 (38.8) & $48(44.0)$ & 37 (38.5) & \\
\hline \multicolumn{7}{|l|}{ School } \\
\hline 1 & $100(24.4)$ & 35 (29.2) & $14(16.5)$ & 31 (28.4) & $20(20.8)$ & \multirow[t]{3}{*}{.294} \\
\hline 2 & $240(58.5)$ & $63(2.5)$ & $55(64.7)$ & $60(55.1)$ & $62(64.6)$ & \\
\hline 3 & $70(17.1)$ & 22 (18.3) & $16(18.8)$ & $18(16.5)$ & $14(16.6)$ & \\
\hline \multicolumn{7}{|l|}{ Grade } \\
\hline $1-3$ & $208(50.7)$ & $61(50.8)$ & $47(55.3)$ & $52(47.7)$ & $48(50.0)$ & \multirow[t]{2}{*}{.770} \\
\hline $4-6$ & 202 (49.3) & 59 (49.2) & $38(44.7)$ & $57(52.3)$ & $48(50.0)$ & \\
\hline \multicolumn{7}{|c|}{ Able to read } \\
\hline Yes & 376 (91.7) & $109(90.8)$ & 78 (91.8) & $100(91.7)$ & 89 (92.7) & \multirow[t]{2}{*}{.970} \\
\hline No & 34 (8.3) & $11(9.2)$ & $7(8.2)$ & $9(8.3)$ & $7(7.3)$ & \\
\hline
\end{tabular}

\section{Overall Objective Understanding Of WI}

Overall, WL led to a higher proportion of children correctly choosing the healthiest option (WL: $59.4 \%, 95 \% \mathrm{Cl}$ :

48.1,70.7; NF: 27.3, 95\% Cl: 22.2, 32.4), the least healthy option (WL: 54.1, 95\% Cl: 32.7, 75.5; NF: 21.5\%, 95\% Cl; 18.4, 24.4), and both (the healthiest and the least healthy option) (WL: 56.8, 95\% Cl: 40.8, 72.8; NF: 24.3\%, 95\% Cl: 20.4, 28.3) compared to NF ( $p$ values < 0.05) (Table 2). Similar results were observed across traditional and numeric WL and most food categories ( $p$ values $<0.05$ ), however, no differences in the proportion of children correctly choosing the healthiest candy were observed between WL and NF. (Table 2) Among children who could not read $(n=34)$, WL also led to a higher proportion of children identifying the least healthy products such as beverages (21.9\% NF vs $30.9 \% \mathrm{WL}, \mathrm{p}<0.05$ ) (data not shown). 
Table 2

Adjusted $^{1}$ proportions of children correctly choosing the healthiest option, the least healthy option and both, across study groups.

\begin{tabular}{|c|c|c|}
\hline Study groups & $\begin{array}{l}N^{2} \\
(n=203)\end{array}$ & $\begin{array}{l}\mathrm{WL}^{2} \\
(\mathrm{n}=205)\end{array}$ \\
\hline & $\%(95 \% \mathrm{Cl})$ & $\%(95 \% \mathrm{Cl})$ \\
\hline Correctly choosing the healthiest product overall* & $27.3(22.2,32.4)$ & $59.4(48.1,70.7)$ \\
\hline Traditional WL & $27.0(8.9,45.2)$ & $65.0(54.9,75.1)$ \\
\hline Beverages & $24.9(10.7,39.1)$ & $53.7(45.7,61.7)$ \\
\hline Breakfast cereals & $14.1(9.3,18.8)$ & $66.4(56.9,75.8)$ \\
\hline Dairy beverages & $40.6(33.0,48.1)$ & $77.2(68.6,85.9)$ \\
\hline Numeric WL & $27.9(14.2,41.6)$ & $51.2(37.1,65.3)$ \\
\hline Juices in returnable packaging & $32.8(25.9,39.6)$ & $55.1(44.8,65.3)$ \\
\hline Cookies & $20.9(14.0,27.9)$ & $47.7(44.5,51.0)$ \\
\hline Candies & $49.2(45.6,52.8)$ & $45.1(40.5,49.7)$ \\
\hline Correctly choosing the unhealthiest product overall* & $21.5(18.4,24.4)$ & $54.1(32.7,75.5)$ \\
\hline Traditional WL & $16.9(13.3,20.5)$ & $52.4(31.6,73.1)$ \\
\hline Beverages & $19.6(15.7,23.5)$ & $44.8(37.6,51.9)$ \\
\hline Breakfast cereals & $9.1(3.1,15.3)$ & $55.8(45.0,66.6)$ \\
\hline Dairy beverages & $20.1(18.0,22.2)$ & $57.0(46.9,67.1)$ \\
\hline Numeric $W L$ & $28.7(26.1,31.4)$ & $56.8(35.4,78.2)$ \\
\hline Juices in returnable packaging & $35.6(32.8,38.5)$ & $64.3(58.6,70.0)$ \\
\hline Cookies & $21.1(19.5,22.6)$ & $49.7(35.2,64.2)$ \\
\hline Candies & $26.5(15.1,37.9)$ & $52.9(40.3,65.4)$ \\
\hline Correctly choosing the healthiest and the least healthy product overall* & $24.3(20.4,28.3)$ & $56.8(40.8,72.8)$ \\
\hline \multicolumn{3}{|c|}{${ }^{1}$ Adjusted proportions estimated using logistic regression models adjusted by sex, age and school cluster } \\
\hline \multicolumn{3}{|l|}{2 Includes both NF groups (NF and NF $+C$ ) or both WL groups (WL and $W L+C)$} \\
\hline
\end{tabular}

\section{Overall Time Required To Choose Products}


Overall, we did not find differences between NF and WL groups in the time required to identify the healthiest or the unhealthiest product. However, differences within food categories were observed (Suppl. Table 2). Children assigned to WL groups spent less time choosing the healthiest breakfast cereal (11.8 seconds, 95\% Cl: 10-13.7), the healthiest juice $(9.7$ seconds, $95 \% \mathrm{Cl}: 8.5,10.9)$, and the least healthy breakfast cereal $(18.0$ seconds, $95 \% \mathrm{Cl}: 15.4,20.6)$, in comparison to those assigned to NF groups $(16.1,12.1$ and 24.1 seconds respectively, $\mathrm{p}<0.05)$. In contrast, WL led to higher times required to choose the healthiest $(10.4,95 \% \mathrm{Cl}$ : $9.3-11.4)$ and the least healthy cookies $(22.6,95 \% \mathrm{Cl}$ : $20.7,24.5)$ compared to NF (12.4 and 15.2 respectively, $p<0.05)$.

\section{Traditional versus numeric WL}

Overall, the objective understanding of traditional WL was higher $(28.7 \%, 95 \% \mathrm{Cl}$ : $22.8-35.4)$ than the numeric WL $(19.0 \%, 95 \% \mathrm{Cl}: 14.2-25.0, \mathrm{p}<0.05)$ (Table 3). This result was consistent for choosing the healthiest product (WL: $46.1 \%$ vs WL-N: $33.6 \%, p<0.05)$ and the least healthy one (WL: 38.4\% vs WL-N: $31.7 \%, p<0.05)($ Table 3$)$. Similarly, the median of time required to identify the products was lower for WL (14.6 seconds) than for numeric WL (17.8 seconds, $p<0.05)$. Supplementary table 3 shows the adjusted proportions of children correctly choosing the healthiest and the unhealthiest products, across study groups, type of warning label and food group.

Table 3

Proportion of children correctly choosing the healthiest option, the least healthy option and both, and time required to make these decisions, across numeric and traditional warning labels

\begin{tabular}{|c|c|c|}
\hline$n=205$ & Numeric WL & Traditional WL \\
\hline & $\%(95 \% \mathrm{Cl})$ & $\%(95 \% \mathrm{Cl})$ \\
\hline Correctly choosing the healthiest product & $33.6(27.5,40.4)$ & $46.1(39.3,53.0)$ \\
\hline Correctly choosing the least healthy product & $31.7(25.6,38.4)$ & $38.4(31.9,45.3)$ \\
\hline \multirow[t]{2}{*}{ Correctly choosing the healthiest and the least healthy product overall } & $19.0(14.2,25.0)$ & $28.7(22.8,35.4)$ \\
\hline & Median $(95 \% \mathrm{Cl})$ & Median $(95 \% \mathrm{Cl})$ \\
\hline Time to choose the healthiest product (seconds) & $14.2(11.2,18.2)$ & $11.0(6.4,15.0)$ \\
\hline Time to choose the least healthy product (seconds) & $21.73(17.6,27.1)$ & $17.7(13.0,24.3)$ \\
\hline Time to choose the healthiest or the least healthy product (seconds) & $17.8(14.7,22.3)$ & $14.6(8.8,19.7)$ \\
\hline \multicolumn{3}{|l|}{ WL: warning label. } \\
\hline Bolds indicate significantly different $(p<0.05)$ to numeric WL. & & \\
\hline
\end{tabular}

\section{Cartoon Characters Versus No Cartoon Characters}

Among children assigned to NF groups (i.e., products without WL), cartoon characters led to a lower proportion $(11.6 \%, 95 \% \mathrm{Cl}: 4.2,19.1)$ of children correctly identifying the least healthy option when considering regular size products compared to no cartoons $(20.6 \%, 95 \% \mathrm{Cl}$ : $19.6,21.5 \%)$. Across food groups, this effect was only observed among dairy beverages $(10.4 \%, 95 \% \mathrm{Cl}: 3.0,17.8)$. 
Among children assigned to WL groups (i.e., products labeled with WL), cartoon characters led to a lower proportion $(48.9 \%, 95 \% \mathrm{Cl}: 25.6,72.4)$ of children correctly identifying the least healthy option compared to no cartoon characters (58.7\%, 95\% Cl: 36.4, 81.1) (Table 4). This same effect was observed among products labeled with traditional WL, such as breakfast cereals and dairy beverages, but not those with numeric WL (i.e., juices in returnable packaging and cookies). No other effects of cartoon characters were observed. 
Table 4

Proportion of children correctly choosing the healthiest option, the least healthy option and both, across cartoon character groups.

\begin{tabular}{|c|c|c|c|c|}
\hline & \multicolumn{2}{|l|}{ NF group } & \multicolumn{2}{|l|}{ WL group } \\
\hline & & $N F+C$ & & \\
\hline & $(n=120)$ & $(n=83)$ & $(n=109)$ & $(n=96)$ \\
\hline & $\%(95 \% \mathrm{Cl})$ & $\%(95 \% \mathrm{Cl})$ & $\%(95 \% \mathrm{Cl})$ & $\%(95 \% \mathrm{Cl})$ \\
\hline Correctly choosing the healthiest product overall* & $\begin{array}{l}29.7(18.0 \\
41.4)\end{array}$ & $\begin{array}{l}24.0(17 \\
31.1)\end{array}$ & $\begin{array}{l}63.9(49.8, \\
77.9)\end{array}$ & $\begin{array}{l}54.3(28.9, \\
79.8)\end{array}$ \\
\hline Beverages & $\begin{array}{l}32.1(10.5 \\
53.8)\end{array}$ & $\begin{array}{l}14.9(13.5, \\
16.3)\end{array}$ & $\begin{array}{l}62.7(46.3 \\
79.0)\end{array}$ & $\begin{array}{l}43.6(32.1, \\
55.2)\end{array}$ \\
\hline Breakfast cereals & $\begin{array}{l}11.1(4, \\
18.2)\end{array}$ & $\begin{array}{l}18.4(12.8 \\
24)\end{array}$ & $\begin{array}{l}71.3(61.4, \\
81.3)\end{array}$ & $\begin{array}{l}60.7(46 \\
75.5)\end{array}$ \\
\hline Dairy beverages & $\begin{array}{l}43.3(33.3 \\
53.2)\end{array}$ & $\begin{array}{l}36.9(29.5 \\
44.2)\end{array}$ & $\begin{array}{l}76.5(69.9 \\
83.2)\end{array}$ & $\begin{array}{l}78.0(66.8, \\
89.3)\end{array}$ \\
\hline Juices in returnable packaging & $\begin{array}{l}33.6(27.2 \\
40.1)\end{array}$ & $\begin{array}{l}31.6(22.6 \\
40.7)\end{array}$ & $\begin{array}{l}58.6(44.9 \\
72.2)\end{array}$ & $\begin{array}{l}51.2(42.2, \\
60.2)\end{array}$ \\
\hline Cookies & $\begin{array}{l}23.8(18.9 \\
28.7)\end{array}$ & $\begin{array}{l}17.1(6.0 \\
28.2)\end{array}$ & $\begin{array}{l}53.3(41.2 \\
65.4)\end{array}$ & $\begin{array}{l}41.5(21.6 \\
61.3)\end{array}$ \\
\hline Candies & NA & NA & NA & NA \\
\hline Correctly choosing the unhealthiest product overall* & $\begin{array}{l}23.8(19.2, \\
28.5)\end{array}$ & $\begin{array}{l}18.1(9.6 \\
26.5)\end{array}$ & $\begin{array}{l}58.7(36.4, \\
81.1)\end{array}$ & $\begin{array}{l}48.9(25.6, \\
72.4)\end{array}$ \\
\hline Beverages & $\begin{array}{l}22.1(18.8 \\
25.3)\end{array}$ & $\begin{array}{l}\text { 16.1 (8.7, } \\
23.6)\end{array}$ & $\begin{array}{l}45.8(35.4 \\
56.1)\end{array}$ & $\begin{array}{l}43.6(38 \\
49.3)\end{array}$ \\
\hline Breakfast cereals & $\begin{array}{l}10.4(5.8 \\
15)\end{array}$ & $\begin{array}{l}7.5(0.1 \\
16.8)\end{array}$ & $\begin{array}{l}67.9(52, \\
83.8)\end{array}$ & $\begin{array}{l}42.3(33.8, \\
50.7)\end{array}$ \\
\hline Dairy beverages & $\begin{array}{l}27.1(25.8 \\
28.3)\end{array}$ & $\begin{array}{l}\text { 10.4 (3.0, } \\
17.8)\end{array}$ & $\begin{array}{l}65.2(54.5 \\
75.8)\end{array}$ & $\begin{array}{l}47.9(35.8, \\
60)\end{array}$ \\
\hline Juices in returnable packaging & $\begin{array}{l}33.7(26.4 \\
40.9)\end{array}$ & $\begin{array}{l}38.5(36.4 \\
40.6)\end{array}$ & $\begin{array}{l}68.4(65.5 \\
71.4)\end{array}$ & $\begin{array}{l}59.6(47.9, \\
71.4)\end{array}$ \\
\hline Cookies & $\begin{array}{l}22.9(19.4 \\
26.5)\end{array}$ & $\begin{array}{l}18.5(9.8 \\
27.2)\end{array}$ & $\begin{array}{l}48.6(35.3 \\
61.9)\end{array}$ & $\begin{array}{l}51.1(35.3, \\
66.9)\end{array}$ \\
\hline Candies & NA & NA & NA & NA \\
\hline $\begin{array}{l}\text { Correctly choosing the healthiest and the } \\
\text { unhealthiest product overall }\end{array}$ & $\begin{array}{l}26.7(18.7 \\
34.7)\end{array}$ & $\begin{array}{l}20.9(14.9 \\
27.1)\end{array}$ & $\begin{array}{l}61.5(47.9 \\
75.1)\end{array}$ & $\begin{array}{l}51.6(27.5, \\
75.6)\end{array}$ \\
\hline
\end{tabular}

Communication strategies to explain the correct use of warning labels 
Among children assigned to WL groups, the video led to higher odds (OR $=2.23,95 \% \mathrm{Cl}: 1.42-3.53, \mathrm{p}<0.05)$ for correctly choosing the healthiest and the least healthy option compared to the posters. Similar results were observed when choosing he healthiest option (OR $=2.41,95 \% \mathrm{Cl}: 1.44-4.04, \mathrm{p}<0.05)$, the least healthy option $(\mathrm{OR}=1.57$, 95\%Cl: $1.23-1.99, \mathrm{p}<0.05)$, and across numeric or traditional WL. (Table 5 )

Table 5

Odds for correctly choosing the healthiest or the least healthy option among children assigned to warning label groups, by communication strategy $(n=203)$.

\begin{tabular}{|l|c|}
\hline & O.R. $(95 \% \mathrm{Cl})^{1}$ \\
\hline Correctly choosing the healthiest or the least healthy product overall & $2.23(1.42,3.53)$ \\
\hline Correctly choosing the healthiest product overall & $2.41(1.44,4.04)$ \\
\hline Traditional WL & $2.31(1.56,3.43)$ \\
\hline Numeric WL & $1.62(1.05,2.51)$ \\
\hline Correctly choosing the unhealthiest product overall & $1.57(1.23,1.99)$ \\
\hline Traditional WL & $1.27(1.09,1.49)$ \\
\hline Numeric WL & $1.59(1.09,1.79)$ \\
\hline 1 Odds ratios estimated with a generalized linear models adjusted by sex, age and cluster $($ school). \\
\hline Bolds indicate significant odds (P-value< 0.05$)$ & \\
\hline
\end{tabular}

\section{Discussion}

Results of this randomized experiment indicate that among a sample of Mexican school-aged children WL led to improved identification of healthier and less healthy food products in a reduced time compared to a control condition. Further, results suggest that although traditional WL perform better than numeric WL, both were effective in helping children identify the healthiest and the least healthy product in comparison to control groups. Results also suggest that this effect may be smaller when cartoon characters are displayed on the front of the package of food products, especially unhealthy products. Finally, the video strategy was more effective than posters to communicate the interpretation of how to use the WL among scholar children.

Results of this experiment are in line with other studies suggesting that WL are more effective than control conditions or other labelling formats for helping children and adolescents identify healthier food products. For example, Arrúa et. al, found that among Uruguayan school-aged children WL led to a higher proportion of children correctly identifying healthy food products than multiple-traffic lights [27]. Similarly, Lima et al, found that in 9-12 y old Brazilian children WL reduced the healthfulness perception of frosted flakes compared to the GDA system [28]. Similar results have also been reported among adult populations $[25,28,33]$

This study also provided relevant information regarding the time required to making food choices. Studies among adults report that the time required to select food products is between 0.04 to 18 seconds [35-37], however scarce evidence exists regarding the time required by children to complete similar tasks. According to our results, the time required to identify healthy or unhealthy foods by using WL was shorter than 20 seconds, which is similar to the average time found in Mexican adult consumers when asked to choose the least healthy option among three food 
products [38]. In sum, results of this study support the fact that WL are easily and quickly understood among children attending public schools in Mexico, where some are not able to read yet. Based on the former, it seems fair to suggest that WL in traditional or numeric formats have the potential of being understood among illiterate populations, which are more frequent among low- and middle-income countries.

In our study, we were able to explore differences in the objective understanding of traditional WL as well as numeric WL, a new WL format considered by the Mexican regulation for small products and products in returnable packaging. To date, no other studies have explored the effect of this novel WL approach. However, in line with studies indicating that different formats of WL (i.e., a triangle in Brazil or a magnifying glass in Canada) also may foster better healthy food choices [37], results of this study indicate that numeric WL have the potential to inform children when products have a higher content of critical nutrients. Considering that a high proportion of small products are products targeting young populations (e.g., candies, chocolates, snacks), and previous experiences in other countries indicate that these products are not labelled [39], it seems reasonable to consider an alternate strategy to foster healthier food choices among these sort of products. Hence, it seems possible that labelling regulations considering numeric WL for small products may be more effective in promoting healthy food choices compared to those only considering traditional WL. However, the effect of any front-of-pack labelling is influenced not only by the objective understanding of the label, but by a myriad of factors which were not considered in this study $[25,26]$. Future studies exploring the real-life effect of WL among Mexican populations may help address this question.

Children are a main target for food marketing, with the strongest strategy focusing on generating remarkable familiarity mostly with contextual animated Cartoon characters [40]. In our experiment, cartoon characters displayed on the front of the package of food products labelled with WL led to a lower proportion of children correctly identifying the least healthy product, but not the healthiest option. Contrary to our expectations, for some food groups as the breakfast cereals and milk, products with cartoon characters were perceived as the unhealthiest items (data not shown). This finding is in concordance with other studies among adults showing that products with cartoon characters were perceived as of lower nutritional quality when compared to products without these characters [41]. Taken together, results indicate that cartoon characters influence the effect of WL underscoring the need of regulating marketing strategies directed to children on unhealthy food products along with the implementation of front-of-package labelling regulations.

The need of effective communication strategies when implementing new front of pack labelling regulations has been highlighted by international agencies [42]. However, scarce evidence exists on the most effective formats. A recent study found that emoji was useful to associate food healthfulness perception with child emotions by using WL [31]. In our study, we found that a short one-minute video was more effective than emoji posters to communicate the correct interpretation of the WL. It is possible that exposures to more detailed or different explanations could have increased effects in the objective understanding of WL, especially for younger children [43]. Therefore, the authors recommend that NOM-051 implementation will be accompanied by a mass media campaign to inform about the correct interpretation of WL system and the inclusion of informative videos.

To our knowledge, this is the first randomized experiment testing the objective understanding of WL including the new numeric format, among Mexican school-aged children. Strengths of this study include the use of a randomized design, ensuring that the influence of confounding from observed and unobserved factors was minimal. Also, the study considered different types and sizes of foods and beverages, increasing the statistical power of our results. Finally, this study provides key information for decision-makers in Mexico regarding the objective understanding of 
the Mexican WL and contributes to fill the gap in knowledge regarding objective understanding of WL in children [27, 28]. However, results of this study should be interpreted considering its limitations. First, the recruitment process was not intended to provide a representative sample of Mexican school-aged children. However, the sample approximates the demographic profile of the Mexican school-aged children attending public schools, representing children from the most vulnerable populations in Mexico. Second, we conducted an experiment in a controlled situation and using mock products, limiting the ability of the study to replicate a real shopping experience. Finally, only one type of cartoon character was considered. Although this character was among the most popular during the field work period, it is possible that a dilution of the effect observed of the cartoon character in the objective understanding of the WL in comparison to use different cartoon character in the products.

\section{Conclusions}

The results of this study contribute to support the evidence regarding the potential of WL to help young consumers identify healthy and least healthy packaged-foods choices in an easy and quick manner. Importantly, numeric WL considered in the Mexican front-of-pack-labeling regulation also seemed to be effective to help children identify healthy and unhealthy products, suggesting that this labels aimed at unhealthy small products $\left(\leq 40 \mathrm{~cm}^{2}\right)$ may effectively communicate the excessive content of nutrients of concern among children. Results also indicate that cartoon characters displayed on the front-of-the package may reduce the objective understanding of the WL, underscoring the need to regulate advertising directed to children along with the implementation of front-of-pack labeling regulations. Finally, results can be drawn on to inform the work of other researchers or stakeholders interested in designing communication campaigns aimed at improving the use and understanding of front of pack labeling formats for this population groups.

\section{Abbreviations}

FOPL; front-of-the-pack-labeling, WL; warning labels, NF; nutrition facts, GDA; Guideline Daily Amount; WLC; warning labels and cartoon characters; NFC; nutrition facts and cartoon characters.

\section{Declarations}

- Ethics approval and consent to participate: The Ethics, Research and Biosafety committees of the Mexican National Institute of Public Health evaluated and approved this study (approval number: 7-68S4-P62-19). Written consent forms were sent home with children and only those with consent to participate by their parents or guardians were included. Before starting study procedures, children were asked to assent to participate in the study.

- Consent for publication: not applicable.

- Availability of data and materials. The datasets used and/or analyzed during the current study are available from the corresponding author on reasonable request.

- Competing interests. The authors declare that they have no competing interests

- Funding: This work was supported by AC, JVM, GA, CN and Bloomberg philantrophies [grant number \#43003].

- Authors' contributions: CMA conceived, designed and executed the study, performed the statistical analysis, interpreted the results and drafted the manuscript. VMJ and JA helped design and execute the study, processed and cleaned the database, and revised the manuscript critically for intellectual content. NC helped writing the methodology, executing the study, interpreting the results and revising the manuscript for intellectual content. 
BS, GA, AEML, OA, MSA, and CCC helped execute the study and revised the manuscript critically for intellectual content. JA helped design the study, revised the manuscript critically for intellectual content, had full access to all the data in the study and has final responsibility for the decision to submit for publication. All authors read and approved the final manuscript.

- Acknowledgements. Authors would like to acknowledge González-Vallejo Blanca, García-Alanis Aide Y, MorenoMora Ailyn, Pérez-Alvarado Dulce M for their support during data collection.

\section{References}

1. Obesity Update 2017. Available from: https://www.oecd.org/els/health-systems/Obesity-Update-2017.pdf.

2. NCD Risk Factor Collaboration (NCD-RisC). Worldwide trends in body-mass index, underweight, overweight, and obesity from 1975 to 2016: a pooled analysis of 2416 population-based measurement studies in 128.9 million children, adolescents, and adults. Lancet. 2017 Dec16; 390(10113):2627-2642 doi:10.1016/S01406736(17)32129-3.

3. Gakidou E, Marie Ng, Tom Fleming, Margaret Robinson, Blake Thomson, Nicholas Graetz, Christopher Margono, Erin C Mullany, Stan Biryukov, Cristiana Abbafati, Semaw Ferede Abera. Global, regional and national prevalence of overweight and obesity in children and adults 1980-2013: A systematic analysis. Lancet. 2014 August 30; 384(9945): 766-781. doi:10.1016/S0140-6736(14)60460-8

4. INEGI, Instituto Nacional de Salud Pública, Secretaría de Salud. Encuesta Nacional de Salud y Nutrición ENSANUT 2018. Presentación de resultados. [Internet]. ensanut.insp.mx. 2019. Available from:

https://ensanut.insp.mx/encuestas/ensanut2018/doctos/informes/ensanut_2018_presentacion_resultados.pdf

5. Romieu I, Dossus L, Barquera S, Blottière HM, Franks PW, Gunter M. Energy balance and obesity: what are the main drivers? Cancer Causes Control. 2017 Mar;28(3):247-258. doi: 10.1007/s10552-017-0869-z.

6. Hall K. Ultra-processed diets cause excess calorie intake and weight gain: A one-month inpatient randomized controlled trial of ad libitum food intake. doi: 10.31232/osf.io/w3zh2.

7. Donin AS, Nightingale CM, Owen CG, Rudnicka AR, Perkin MR, Jebb SA. Regular breakfast consumption and type 2 diabetes risk markers in 9- to 10-year-old children in the child heart and health study in England (CHASE): a cross-sectional analysis. PLoS Med. 2014 Sep 2;11(9):e1001703. doi: 10.1371/journal.pmed.1001703.

8. Aburto TC, Pedraza LS, Sánchez-Pimienta TG, Batis C, Rivera JA. Discretionary foods have a high contribution and fruits, vegetables, and legumes have a low contribution to the total energy intake of the Mexican population. J Nutr 2016;146(Suppl):1881S-7S.

9. Corvalán, Reyes, Garmendia, \& Uauy, 2013; Ministerio de Salud Pública, 2015b.

10. Marcela Reyes, María Luisa Garmendia, Sonia Olivares, Claudio Aqueveque, Isabel Zacarías and Camila Corvalán. Development of the Chilean front-of package food warning label.Reyes et al. BMC Public Health (2019) 19:906. https://doi.org/10.1186/s12889-019-7118-1.

11. Ley de promoción de la alimentación saludable para niños, niñas y adolescentes.

[http://plataformacelac.org/ley/15]. Accessed 20 March 2020.

12. Diario Oficial de la Federación. MODIFICACIÓN de la Norma Oficial Mexicana NOM-051-SCFI/SSA1-2010, Especificaciones generales de etiquetado para alimentos y bebidas no alcohólicas preenvasados-Información comercial y sanitaria, publicada el 5 de abril de 2010. Se adicionan los incisos 3.2; 3.5; 3.17; 3.18; 3.21; 3.40; 4.2 .9 con sus subincisos y se ajusta la numeración subsecuente; 4.5 con sus subincisos y el Apéndice Normativo A. Se modifica el capítulo 2 Referencias, así como el literal b) del inciso 3.11; 3.15; 4.2.8.1. Se ajusta 
numeración del capítulo 3 Definiciones, símbolos y abreviaturas. August 14th, 2014.

https://www.dof.gob.mx/nota_detalle.php?codigo=5356328\&fecha=14/08/2014 Accessed in: 20 March, 2020.

13. Ministerio de Salud Pública de Uruguay: Proyecto de decreto del Ministerio de Salud Pública: Rotulado de Alimentos Envasados en Uruguay. In Montevideo, Uruguay; 2017.

14. Duran AC, Ricardo CZ, Mais LA, Bortoletto Martins AP. Role of different nutrient profiling models in identifying targeted foods for front-of-package food labelling in Brazil. Public Health Nutr. 2021 Apr;24(6):1514-1525. doi: $10.1017 /$ S1368980019005056.

15. Taillie, Lindsey Smith, Reyes Marcela, Arantxa Colchero, Popkin Barry, Corvalán, Camila. (2020). An evaluation of Chile's Law of Food Labeling and Advertising on sugar-sweetened beverage purchases from 2015 to 2017: A before-and-after study. PLOS Medicine. 17. 10.1371/journal.pmed.1003015.

16. Corvalán Camila, Reyes Marcela, Garmendia Maria, Uauy Ricardo. (2018). Structural responses to the obesity and non-communicable diseases epidemic: Update on the Chilean law of food labelling and advertising. Obesity Reviews. 20. 10.1111/obr.12802.

17. Perú Retail. Un producto sin octógono nutricional no garantizaría que sea saludable. July 2019. https://www.peru-retail.com/etiqueta-nutricional-producto-sin-octogono-no-avala-saludable/. Accessed on: 20 March, 2020.

18. Gestión. Alimentación saludable: ¿Empresas reducen tamaño de empaques para eliminar octógonos? https://gestion.pe/economia/empresas/alimentacion-saludable-empresas-reducen-tamano-empaques-eliminaroctogonos-262264-noticia/?ref=gesr. Accessed on: 20 March, 2020.

19. Donin AS, Nightingale CM, Owen CG, Rudnicka AR, Perkin MR, Jebb SA, Stephen AM, Sattar N, Cook DG, Whincup PH. Regular breakfast consumption and type 2 diabetes risk markers in 9- to 10-year-old children in the child heart and health study in England (CHASE): a cross-sectional analysis. PLoS Med. 2014;11(9):e1001703. https://doi.org/10.1371/journal.pmed.1001703

20. Ogle AD, Graham DJ, Lucas-Thompson RG, Roberto CA. Influence of Cartoon Media Characters on Children's Attention to and Preference for Food and Beverage Products. JAcad Nutr Diet. 2017;117(2):265-270.e2. https://doi.org/10.1111/obr.12233.

21. Hall KD, Ayuketah A, Brychta R, Cai H, Cassimatis T, Chen KY, Chung ST,Costa E, Courville A, Darcey V. Ultraprocessed diets cause excess calorie intake and weight gain: A one-month inpatient randomized controlled trial of ad libitum food intake. https://doi.org/10.31232/osf.io/w3zh2

22. Till H, Tilley J. Packaging of children's breakfast cereal: manufacturers versus children. Br Food J. 2002;104:9,766-77.https://doi.org/10.1108/00070700210443129

23. Kraak VI, Story M. Influence of food companies' brand mascots and entertainment companies' cartoon media characters on children's diet and health: a systematic review and research needs. Obes Rev. 2015;16(2):107126. doi:10.1111/obr.12237

24. Cairns, G.; Angus, K.; Hastings, G.; Caraher, M. Systematic reviews of the evidence on the nature, extent and effects of food marketing to children. A retrospective summary. Appetite 2013, 62, 209-215.

25. Claudia Nieto, Alejandra Jáuregui, Alejandra Contreras, Thrasher. Understanding and use of food labeling systems among Whites and Latinos in the United States and among Mexicans: Results from the International Food Policy Study, 2017. IJBNPA 2019; 16(1) DOI: 10.1186/s12966-019-0842-1.

26. Vargas-Meza J, Jauregui A, Pacheco Miranda S, Contreras-Manzano A, Barquera S. (2019) Front-of-pack nutritional labels: Understanding by low- and middle-income Mexican consumers. PLoS ONE 14(11): e0225268. https://doi.org/10.1371/journal.pone.0225268

Page 16/21 
27. Arrúa Alejandra, Curutchet Maria, Rey Natalia, Barreto Patricia, Golovchenko Nadya, Sellanes Andrea, Velazco Guillermo, Winokur Medy, Giménez Ana, Ares Gastón. (2017). Impact of front-of-pack nutrition information and label design on children's choice of two snack foods: Comparison of warnings and the traffic-light system. Appetite. 116. 10.1016/j.appet.2017.04.012.

28. Lima M, Ares G, Deliza R. How do front of pack nutrition labels affect healthfulness perception of foods targeted at children? Insights from Brazilian children and parents. Food Qual. Preference. 2018;64:111-119. doi: 10.1016/j.foodqual.2017.10.003.

29. Chilean Ministry of Health. Informe de investigación: Evaluación de mensajes de advertencia en el etiquetado de alimentos mediante grupos focales. Santiago: Chilean Ministry of Health; 2009

30. Ministerio de Salud de Chile: Informe de Evaluación de la Implementación de la Ley sobre composición nutricional de los alimentos y su publicidad. Chile: Chilean Ministry of Health; 2017. p.77.

31. Mayara Lima, Marcela de Alcantara, Inayara B.A. Martins, Gastón Ares, Rosires Deliza. Can front-of-pack nutrition labeling influence children's emotional associations with unhealthy food products? An experiment using emoji.Food Research International. 120;2019. (217-225) https://doi.org/10.1016/j.foodres.2019.02.027

32. Marrón-Ponce JA, Sánchez-Pimienta TG, Louzada MLDC, Batis C. Energy contribution of NOVA food groups and sociodemographic determinants of ultra-processed food consumption in the Mexican population. Public Health Nutr. 2018;21(1):87-93. doi:10.1017/S1368980017002129

33. Jorge Vargas, Alejandra Jáuregui, Alejandra Contreras, Simón Barquera. Acceptability and understanding of front-of-pack nutritional labels: an experimental study in Mexican consumers. BMC Public Health 19(1). DOI: 10.1186/s12889-019-8108-z.

34. Cohen J. Statistical Power Analysis. Current Directions in Psychological Science. 1992;1(3):98-101. doi:10.1111/1467-8721.ep10768783.

35. Milosavljevic M. Consumers can make decisions in as little as a third of a second. Judgement Decis Mak. 2011;6:520-30.

36. Pieters R, Warlop L. Visual attention during brand choice: The impact of time pressure and task motivation. Int $J$ Res Mark. 1999;16:1-16.

37. de Morais Sato P, Mais LA, Khandpur N, Ulian MD, Bortoletto Martins AP, Garcia MT, et al. (2019) Consumers' opinions on warning labels on food packages: A qualitative study in Brazil. PLoS ONE 14(6): e0218813. https://doi.org/10.1371/journal.pone.0218813

38. Tolentino-Mayo L, Rincón-Gallardo Patiño S, Bahena-Espina L, Ríos V, Barquera S. Knowledge and use of nutrient labelling of industrialized foods and beverages in Mexico. Salud Publica Mex 2018;60:328-337. https://doi.org/10.21149/8825

39. Kanter R, Reyes M, Vandevijvere S, Swinburn B, Corvalán, C. (2019). Anticipatory effects of the implementation of the Chilean Law of Food Labeling and Advertising on food and beverage product reformulation. Obesity Reviews. 20 Suppl 2. 10.1111/obr.12870.

40. Mediano F, Reyes M, Taillie TS, Francesca R, Carpentier D. Prevalence of child-directed marketing on breakfast cereal packages before and after Chile's food marketing law: A pre-post quantitative content analysis. International Journal of Environmental Research and Public Health, 2019;16(22). 10.3390/ijerph16224501

41. Contreras-Manzano, A., Jáuregui, A., Nieto, C. et al. The impact of a cartoon character on adults perceptions of Children's breakfast cereals: a randomized experiment. Nutr J 19, 43 (2020). https://doi.org/10.1186/s12937020-00565-5. 
42. Ares G, Machín L, Vidal L, Aschemann-Witzel J, Otterbring T, Curutchet MR, et al. How can we motivate people to use nutritional warnings in decision making? Citizen co-created insights for the development of communication campaigns. Heal Educ Behav. 2019;47(2):321-31.

43. Graham, D. J., Lucas-Thompson, R. G., Mueller, M. P., Jaeb, M., Harnack, L. (2017). Impact of explained v. unexplained front-of-package nutrition labels on parent and child food choices: A randomized trial. Public Health Nutrition, 20, 774-785.

\section{Figures}

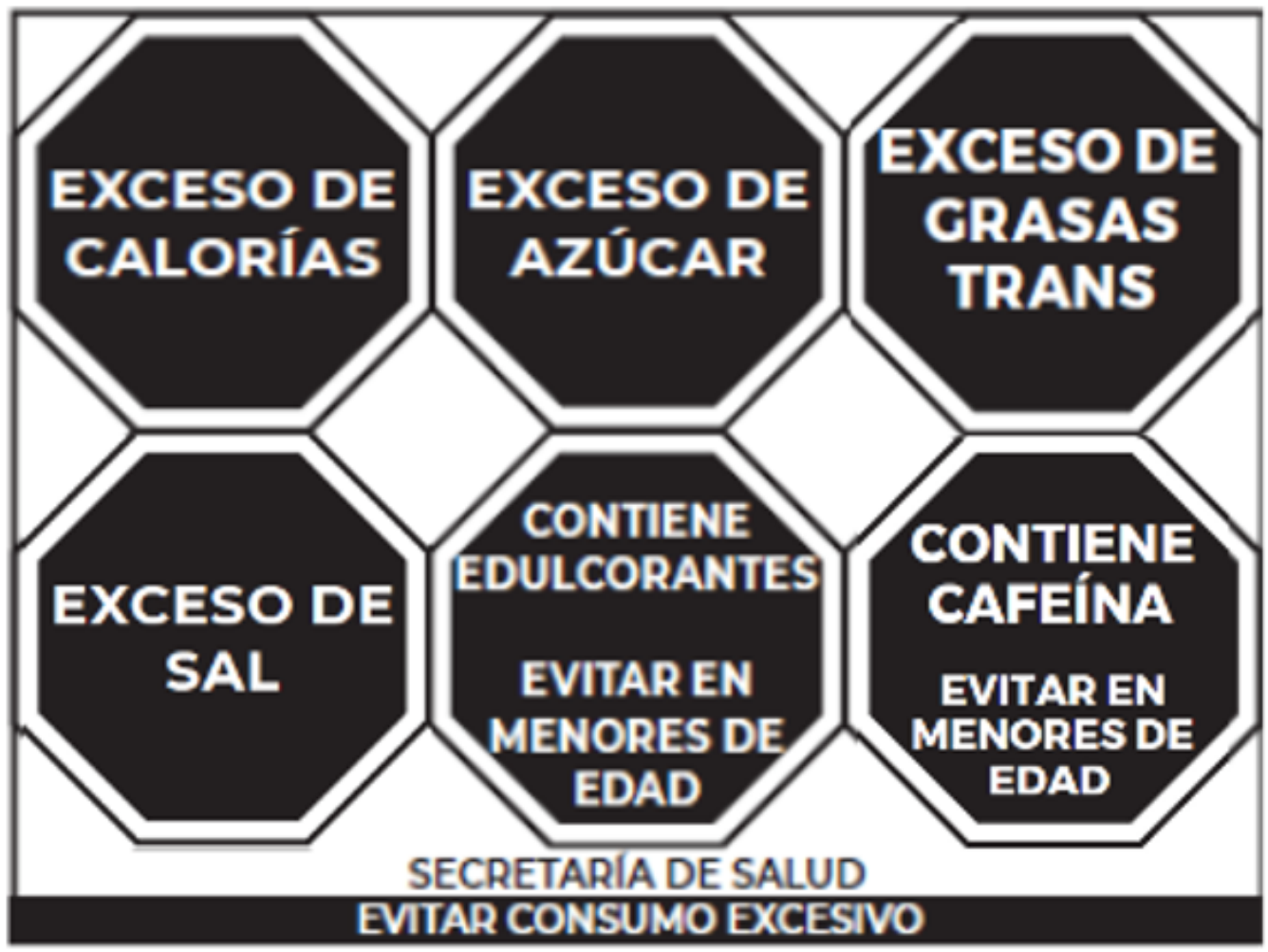

(a)
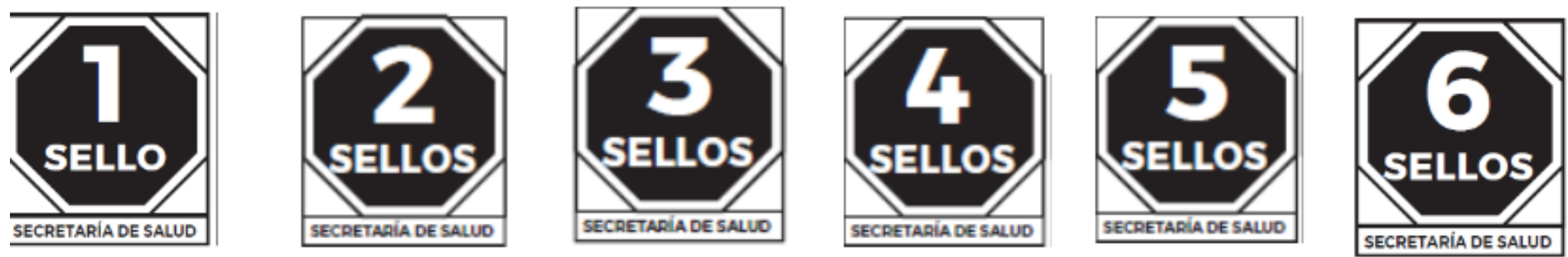

(b)

Figure 1

A. Traditional warning labels B. Numeric warning labels 
(a) Elige productos más saludables Si no tienen sellos mejor!

\section{CHOCOLATE $\times 3$}
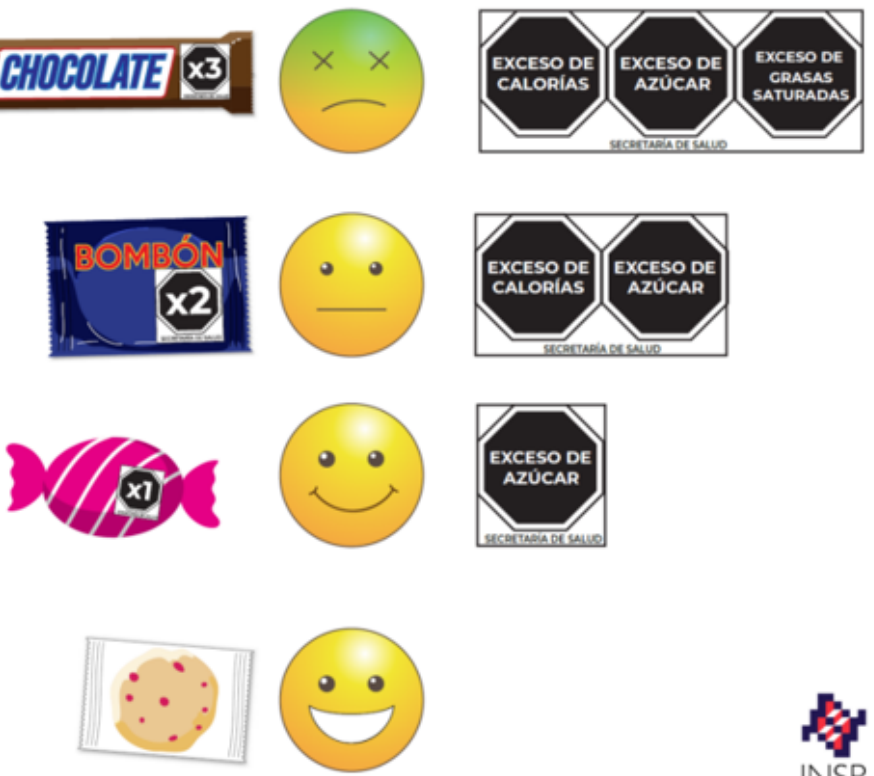

(b)
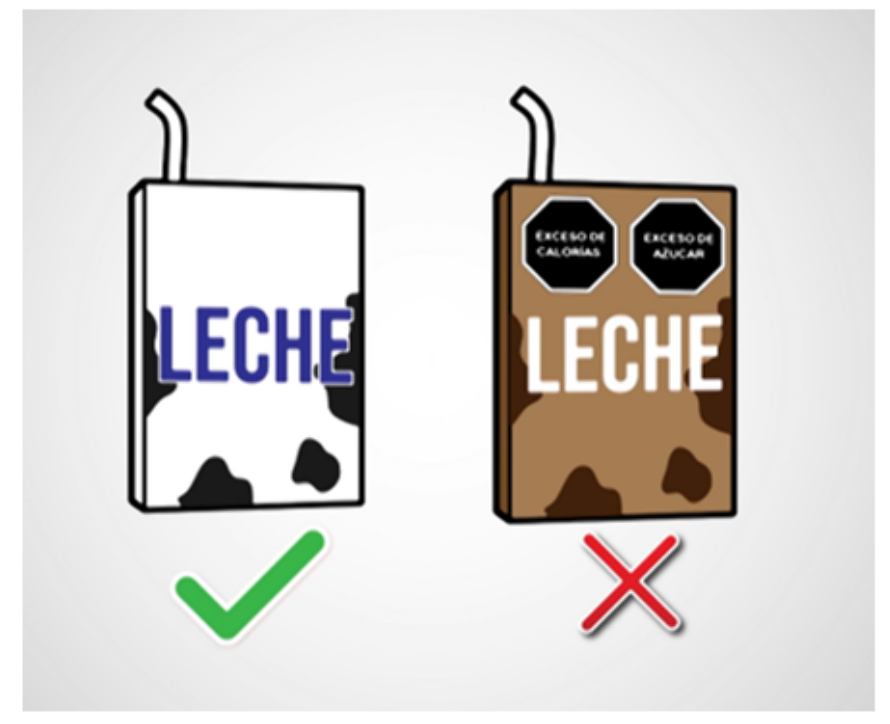

Elige productos más saludables Si no tienen sellos mejor!
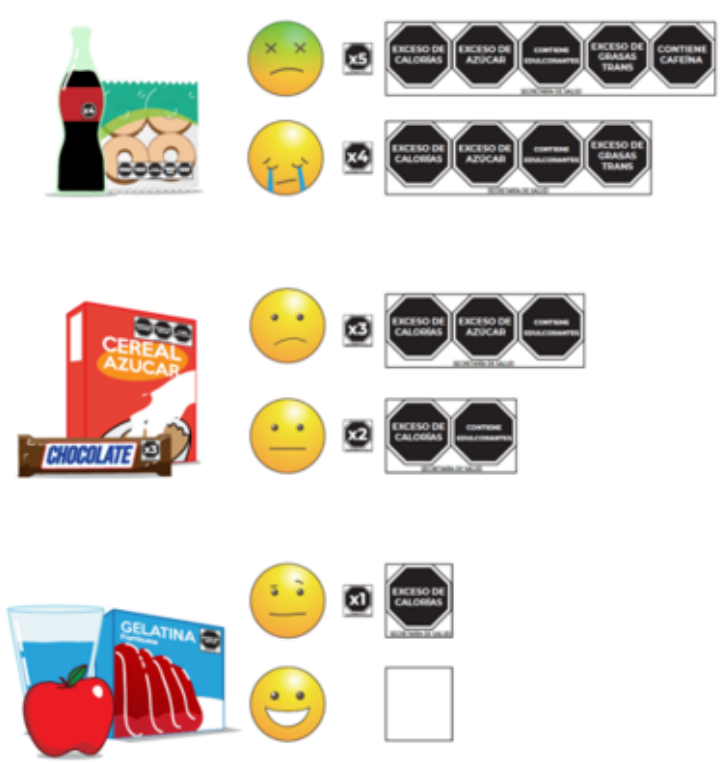

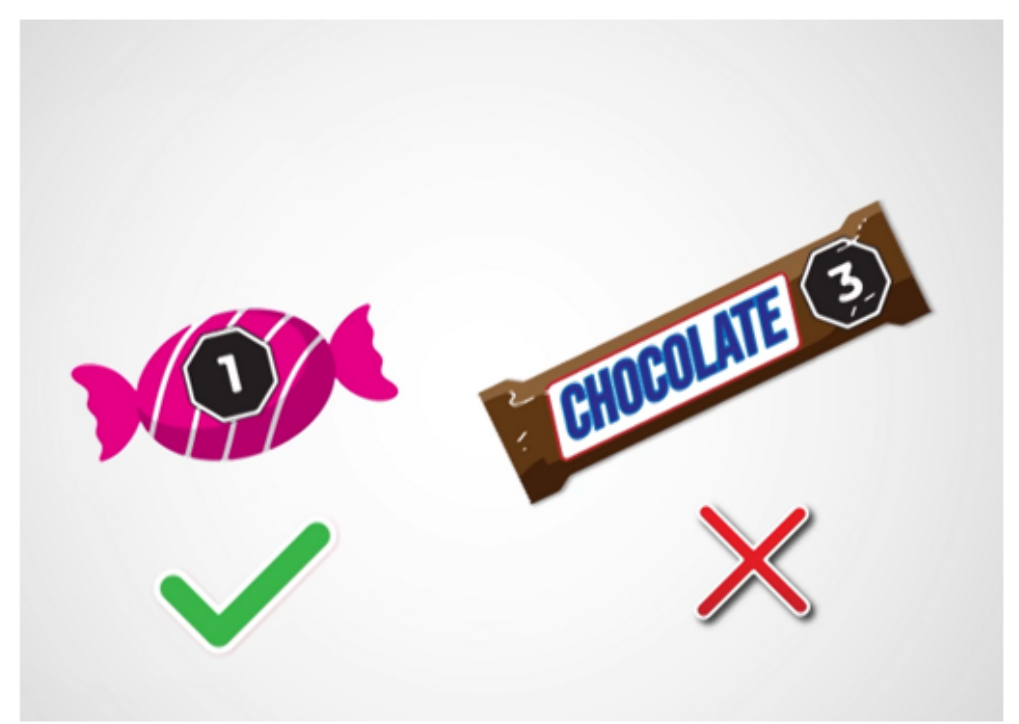

Figure 2

A. WL interpretation posters B. WL interpretation video (LINK) 


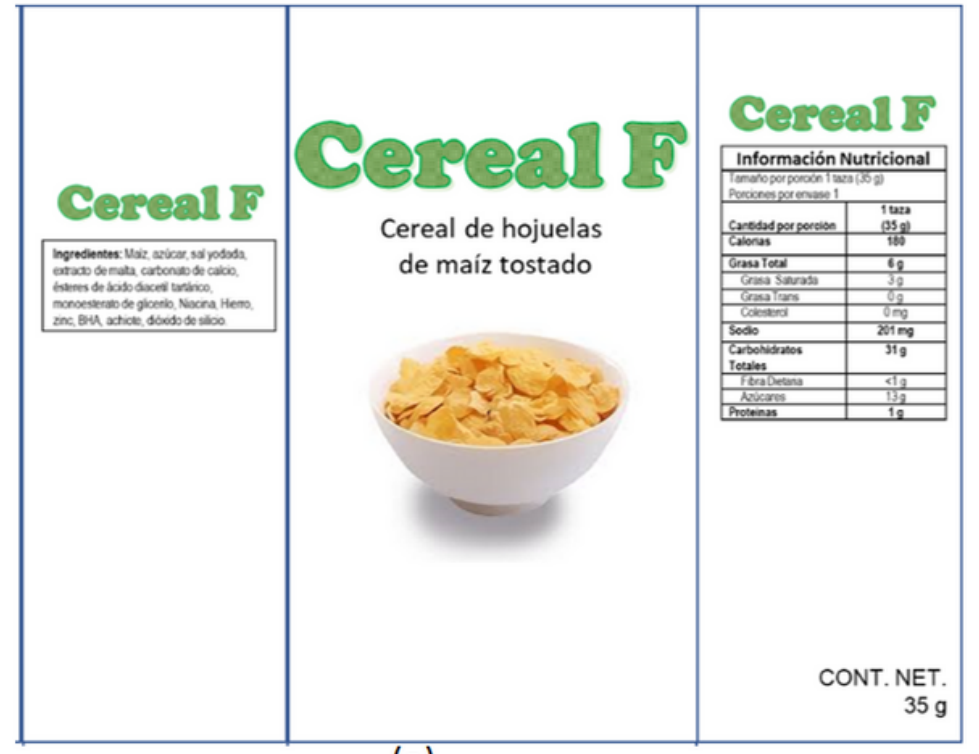

(a)

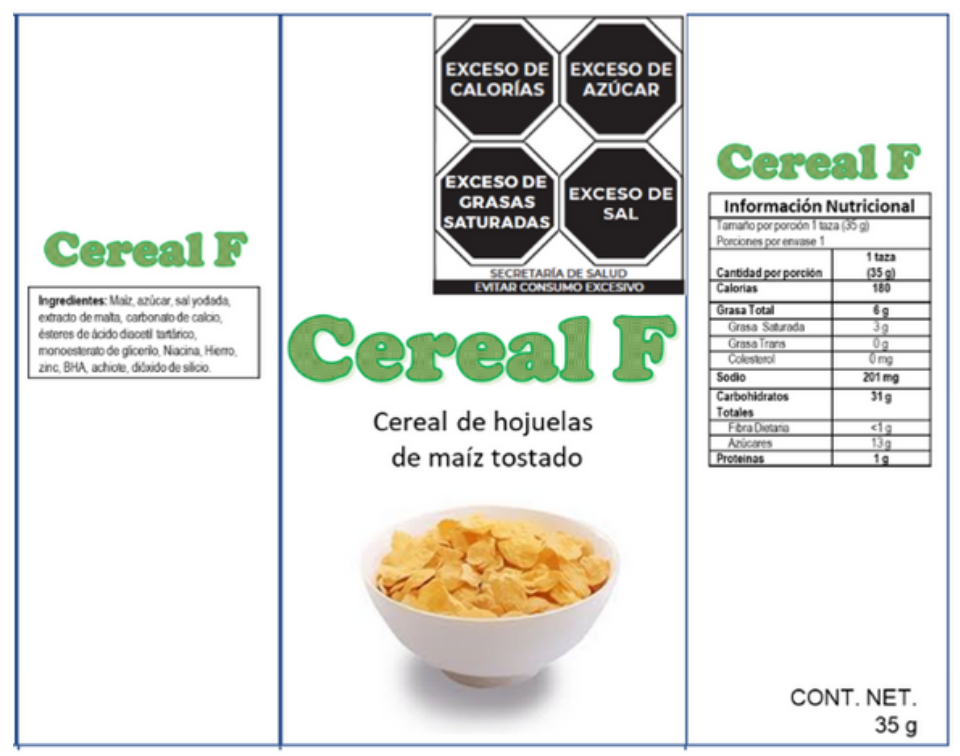

(c)

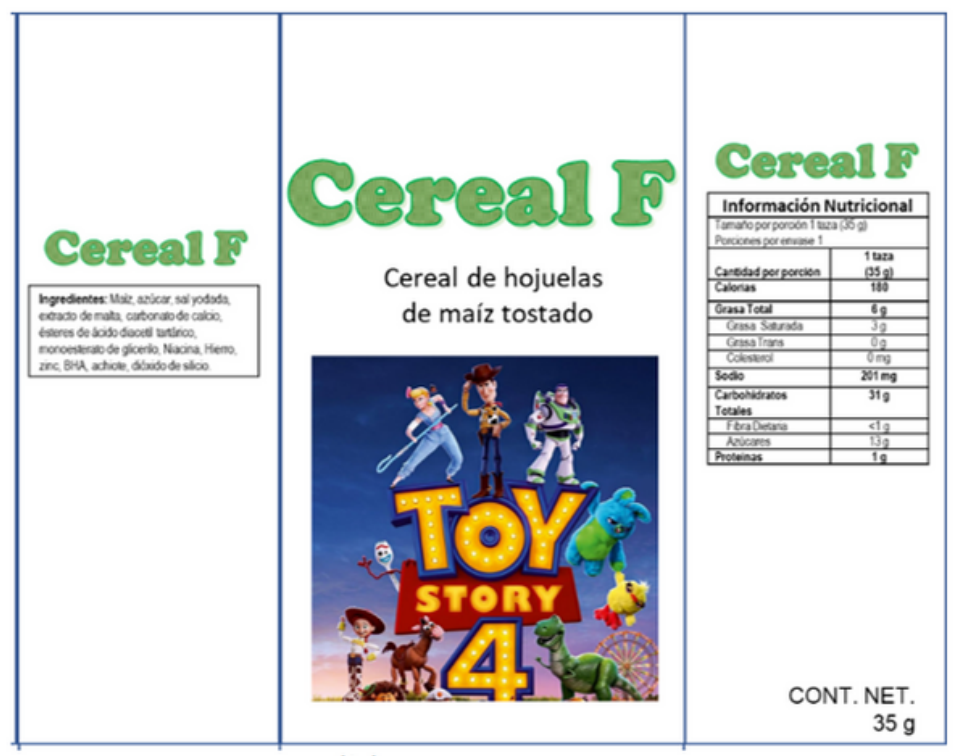

(b)

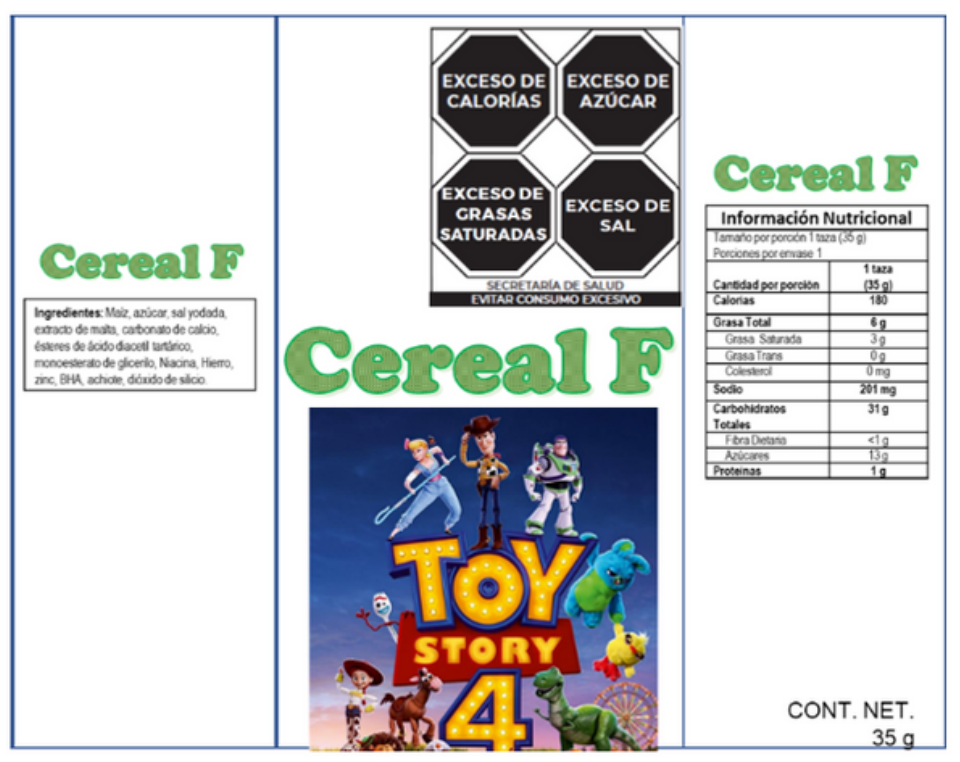

(d)

\section{Figure 3}

A. Nutrition Fact group (Control group) B. Nutrition Fact wit cartoon character C. Warning Labels in captions D. Warning Labels in captions and cartoon character Example of a category of a dummy product bigger than $10 \mathrm{~cm} 2$ by group of study. Basic Breakfast Cereal 
Información Nutrimental. Tamaño de la porción $200 \mathrm{ml}$. Porciones por envase: 2 . Calorias 84 , Grasa Total 0 . Sodio $90 \mathrm{mg}$. Carbohidratos 21 . Azúcares $21 \mathrm{~g}$. Proteinas $0 \mathrm{~g}$.

Ingredientes: Agua Minera Carbonatada, Fructosa, Ácido Citrico,

Concentrado Naranja con Jugo,

Sorbato de Potasio y Benzoato de

Sodio, EDTA Aspartame, Colorantes

Artificiales (Amarillo 6 y Amarillo 5)

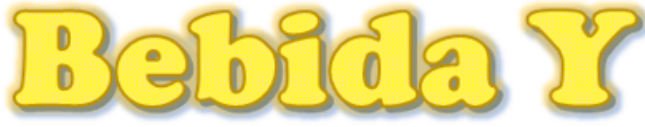

Jugo de naranja

(a)

\begin{abstract}
Información Nutrimental. Tamaño de la porción $200 \mathrm{ml}$. Porciones por envase: 2 . Calorias 84, Grasa Total 0 , Sodio $90 \mathrm{mg}$, Carbohidratos 21 . Azúcares $21 \mathrm{~g}$. Proteinas $0 \mathrm{~g}$.
\end{abstract}

Ingredientes: Agua Mineral Carbonatada, Fructosa, Ácido Círico.

Concentrado Naranja con Jugo,

Sorbato de Potasio y Benzoato de

Sodio, EDTA, Aspartame, Colorantes

Artificiales (Amarillo 6 y Amarillo 5)

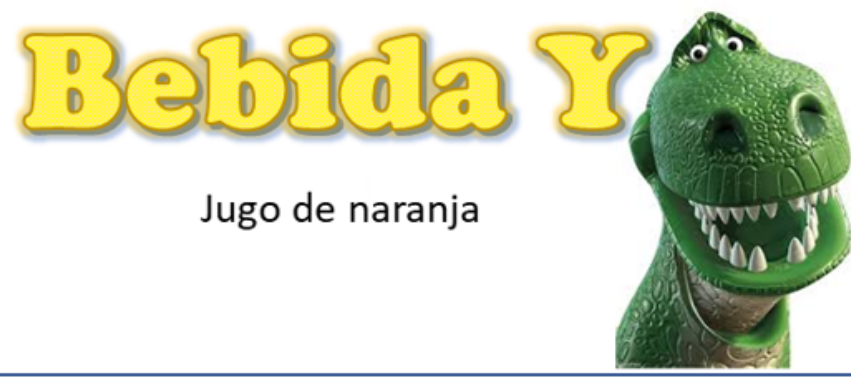

CONT. NET

$400 \mathrm{ml}$

(b)

\section{Información Nutrimental. Tamaño de la porción $200 \mathrm{ml}$. Porciones por envase: 2 . Calorias 84, Grasa Total 0 , Sodio $90 \mathrm{mg}$, Carbohidratos 21 , Azúcares $21 \mathrm{~g}$. Proteinas $0 \mathrm{~g}$}

Ingredientes: Agua Minera

Carbonatada, Fructosa, Ácido Citrico,

Concentrado Naranja con Jugo,

Sorbato de Potasio y Benzoato de

Sodio, EDTA Aspartame, Colorantes

Artificiales (Amarillo 6 y Amarillo 5)
CONT NET, $400 \mathrm{ml}$

(c)

\section{Información Nutrimental. Tamaño de la porción $200 \mathrm{ml}$. Porciones por envase: 2 Calorias 84 , Grasa Tota 0 , Sodio $90 \mathrm{mg}$. Carbohidratos 21 , Azúcares $21 \mathrm{~g}$. Proteinas $0 \mathrm{~g}$.}

Ingredientes: Agua Mineral

Carbonatada, Fructosa, Ácido Citrico,

Concentrado Naranja con Jugo,

Sorbato de Potasio y Benzoato de

Sodio, EDTA, Aspartame, Colorantes

Artifciales (Amarillo 6 y Amarllo 5)

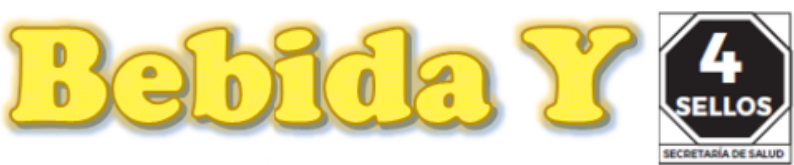

Jugo de naranja
CONT. NET

$400 \mathrm{ml}$

(d)

Figure 4

A. Nutrition facts group. B. Cartoon character C. Numeric Warning Label D. Numeric W with a cartoon character Example of a category of a dummy product smaller than $10 \mathrm{~cm} 2$ by group of study. Orange juice

\section{Supplementary Files}

This is a list of supplementary files associated with this preprint. Click to download.

- Supplementarytables.docx 